\title{
Assessing Food System Sustainability in Rural Cameroon: An Analysis Focused on Food Supply, Food Security and Food Waste
}

\author{
Boris Dinictri SOH WENDA Dorothy ENGWALI FON \\ Dschang School of Agriculture and Environmental Sciences; University of Dschang, Cameroon, P. O. Box: 222
}

FASA, Cameroon

\begin{abstract}
The study is aimed at evaluating the economic, social, and environmental sustainability of the food system prevailing in rural Cameroon, with particular attention to the West region. Food system sustainability is assessed in its economic, social, and environmental domains through household food supply, household food security, and household level food waste respectively. The food consumption score and food consumption nutrition quality analyses were used to measure food security. Frequency tables, cross tables and chi2 tests were applied to data collected from 600 rural households in the West region of Cameroon and it appears that the food system is economically sustainable for most rural households given that only $6.34 \%$ of households consider household food supply to be low. However, the food system is not sustainable in the social domain given that $21.17 \%$ of households are vulnerable to food insecurity and $17.83 \%$ are food insecure. The food consumption score nutrition quality analysis highlights an inadequate consumption of hem-iron, protein and vitamin A rich foods for a considerable number of households. Analysis of household food waste behaviour shows that the food system is relatively sustainable in the environmental domain given that only $1.33 \%$ of households always discard food. There are some trade-offs between the economic and environmental dimensions and between the social and environmental dimensions. Hence, measures taken to improve food system sustainability should consider the existence of such trade-offs.
\end{abstract}

Keywords: Food supply, Food security, Food waste, Food system, Sustainability

DOI: $10.7176 / \mathrm{JESD} / 12-16-04$

Publication date:August $31^{\text {st }} 2021$

\section{Introduction}

In SSA, rural populations depend heavily on agriculture for their income (Sheehan and Barret, 2017) and a major goal of agriculture from its earliest development has been to achieve sufficient food that provides the energy and nutrients needed for a healthy, active life (IOM and NRC, 2015), but this goal is far from being attained as the current food system is unable to ensure food and nutrition security for the global population. Five years after the world committed to ending hunger, food insecurity, and all forms of malnutrition, we are still off track to achieve this objective by 2030 (FAO et al., 2020).

Data tells us that the world is progressing neither towards SDG target 2.1, of ensuring access to safe, nutritious, and sufficient food for all people all year round, nor towards target 2.2, of eradicating all forms of malnutrition (FAO et al., 2020). Because approximately 820 million people are hungry worldwide, and the level of hunger varies substantially depending on the area of the world, with the majority of them living in developing areas (FAO et al., 2019). Also, before the COVID-19 pandemic, almost 690 million people, or $8.9 \%$ of the global population, were undernourished and new estimates have revealed that an additional 60 million people have become affected by hunger since 2014 (FAO et al., 2020).

Malnutrition in its various forms directly affects one third of the global population (Bogard et al., 2018) and the level of food insecurity varies substantially depending on the area of the world, with the majority of them living in developing areas (FAO et al., 2013; FAO et al., 2015; FAO et al., 2017; and FAO et al., 2018). The state of hunger in the world as indicated by the Global Hunger Index (GHI) remains serious (IFPRI et al., 2013, IFPRI et al., 2015; IFPRI et al., 2017; Welthungerhilfe and Concern Worldwide, 2018) and a significant proportion of the global population still does not get enough food (Brown et al., 2014), with the greatest proportion found in developing countries.

Welthungerhilfe and Concern Worldwide (2018) indicated that in Africa south of the Sahara, the undernourishment rate increased marginally between 2009-2011 and 2015-2017 and the under-five mortality rate also increased. The same source reveals that the $2018 \mathrm{GHI}$ score for Cameroon has fallen to 21.1 points, depicting a marginal improvement from the 2017 situation, although still within the serious hunger level threshold.

The recent increase in global hunger, malnutrition and food insecurity is a cause for great concern and poses a significant challenge to international commitments to end hunger by 2030 given that the prevalence of global food insecurity, hunger and malnutrition remains alarming. However, every year, one third of all the food produced for human consumption is either lost or wasted along local, national, regional, and global food supply chains (FSC) (FAO 2011; Capone et al., 2016; FAO, 2018), which is about 1.3 billion tonnes per year (FAO 
2011). It is important to note that food loss and waste (FLW) is occurring at a time of increasing food prices and worsening food insecurity for many (Segré et al., 2014).

Food loss and waste is the wastage of resources, including the land, water, labour, and power used to generate food (FAO, 2018). Studies commissioned by FAO estimated yearly global FLW by quantity at roughly $30 \%$ for cereals, $40-50 \%$ for root crops, fruits and vegetables, $20 \%$ for oilseeds, meat and dairy products, and $35 \%$ for fish (FAO, 2015). Lipinsky et al. (2013) argued that developed countries and industrialized Asian nations are responsible for about $56 \%$ of total food loss and waste, while developing countries for $44 \%$. This issue makes food loss and waste reduction a priority, both at the global and national level (Caldeira et al., 2017).

The prevalence of global food insecurity, hunger and malnutrition remains alarming and this situation is attributed to the food systems, which are focused on increasing yields and economic value, without due consideration of the impact on human health (Bogard et al., 2018). Also, the world's food system is not nutrition-sensitive, efficient, and sustainable to ensure global food security and nutrition (Capone et al., 2016). Whereas, an ideal food system should support human health; be nutritionally adequate and affordable; and provide accessible food for all in a manner that provides a decent living for farmers and farmworkers; and protect natural resources and animal welfare while minimizing environmental impacts (IOM and NRC, 2015). It is therefore essential to conduct food system sustainability assessments.

The aim of this study is to evaluate the economic, social, and environmental sustainability of the food system prevailing in rural Cameroon, with particular attention to the West region.

\section{Literature Review}

\subsection{Approaches to food system sustainability evaluation}

Sustainability means respecting the needs of the present generation without compromising the opportunity of future ones to meet their own needs (World Commission on Environment and Development, 1987 as cited in Peana et al., 2014). While some conceptual and theoretical advances in defining food systems and their related indicators and metrics have shed light on these complex dynamics (Fanzo et al., 2012 as cited in Béné, 2019), researchers and analysts are still struggling with one basic question: how can we define and empirically measure food systems' sustainability? (Béné et al., 2019).

A sustainable food system (SFS) is a food system that delivers food security and nutrition for all in such a way that the economic, social, and environmental basis for generating food security and nutrition for future generations are not compromised (European Commission, 2020; Nguyen, 2018; FAO, 2014). A sustainable food system should thus ensure and contribute to all elements of environmental, social, and economic sustainability (European Commission, 2020). Miller et al. (2020) emphasise that economic, social, and environmental sustainability as well as health are needed for sustainable food systems.

The sustainability of the food system can be explored at different scales (Prosperi et al., 2015). Many criteria are required to accurately assess the sustainability of foods, including multiple nutrition, economic, environmental, and social concerns (Miller et al., 2020). Gulisano et al. (2018) proposed a life cycle approach to evaluating agro-food system sustainability focusing on the environmental, economic, and social domains. Here, the researchers propose the use of life cycle assessment (LCA) to evaluate the environmental impact, the life cycle costing (LCC) to measure the economic impact and the social life cycle assessment (SLCA) to identify and assess social repercussions and implications. The measurement of sustainability should take into account interlinks that have consequences for the environment, the economy, and society through cause-effect relationships (Gulisano et al., 2018).

In the works of Peana et al. (2014), a five-dimensional framework is provided to assess Agri-food systems sustainability. These dimensions are quality, environmental, social, economic, and cultural. The Sustainability Assessment of Food and Agriculture (SAFA) Guidelines (FAO, 2013) offer a globally applicable framework for a comprehensive view of sustainability, covering four dimensions: good governance, environmental integrity, economic resilience, and social well-being. Similarly, Zurek et al. (2018) posit that the four components essential for an integrated assessment of food systems are nutrition and diet, environmental and economic outcomes, and social equity. Also, IFPRI (2015) in analysing food systems looks at four broad outcome groups: food affordability (representing food quantity), food consumption diversity (representing food quality), nutrition and health outcomes, and environmental sustainability. Béné et al. (2019) in designing a global map of food system sustainability also consider four dimensions of sustainability: environment, social, food security and nutrition, and economic.

Nguyen (2018) is in favour of a food system approach to evaluating food system sustainability. The author believes that a food systems approach is a way of thinking and doing that considers the food system in its totality, taking into account all the elements, their relationships, and related effects. A systems approach to measuring performance is about assessing the performance of the food system along all sustainability dimensions: economic, social, and environmental. Similarly, the European Commission holds that to achieve a sustainable food system for the EU, the central goal of all relevant policy development and assessment must be to ensure 
food sustainability in all its aspects: environmental, social, and economic (European Commission, 2020).

The framework proposed by Nguyen (2018) states that in the economic dimension, a food system is considered sustainable if the activities conducted by each food system actor or support service provider are commercially or fiscally viable. The activities should generate benefits, or economic value-added, for all categories of stakeholders: wages for workers, taxes for governments, profits for enterprises, and food supply improvements for consumers (Nguyen, 2018). On the social dimension, a food system is considered sustainable when there is equity in the distribution of the economic value added, taking into account vulnerable groups categorized by gender, age, race, and so on. Of fundamental importance, food system activities need to contribute to the advancement of important socio-cultural outcomes, such as nutrition and health, traditions, labour conditions, and animal welfare (Nguyen, 2018). On the environmental dimension, sustainability is determined by ensuring that the impacts of food system activities on the surrounding natural environment are neutral or positive, taking into consideration biodiversity, water, soil, animal and plant health, the carbon footprint, the water footprint, food loss and waste, and toxicity (Nguyen, 2018).

This holistic vision of food system sustainability evaluation makes it possible to identify potential synergies and to reveal trade-offs between the three dimensions, so as to ensure that while the targeted impact is positive, the overall impact on the system will also be positive (Nguyen, 2018). However, when using the food system approach, there are trade-offs to be made (i.e. between key priorities of the food system: inclusive poverty reduction, increased agricultural productivity, improved nutrition, and enhanced environmental sustainability), but there are also opportunities to simultaneously accomplish multiple objectives (Nguyen, 2018).

Figure 1 summarises the dimensions of food system sustainability and the corresponding indicators for each dimension.

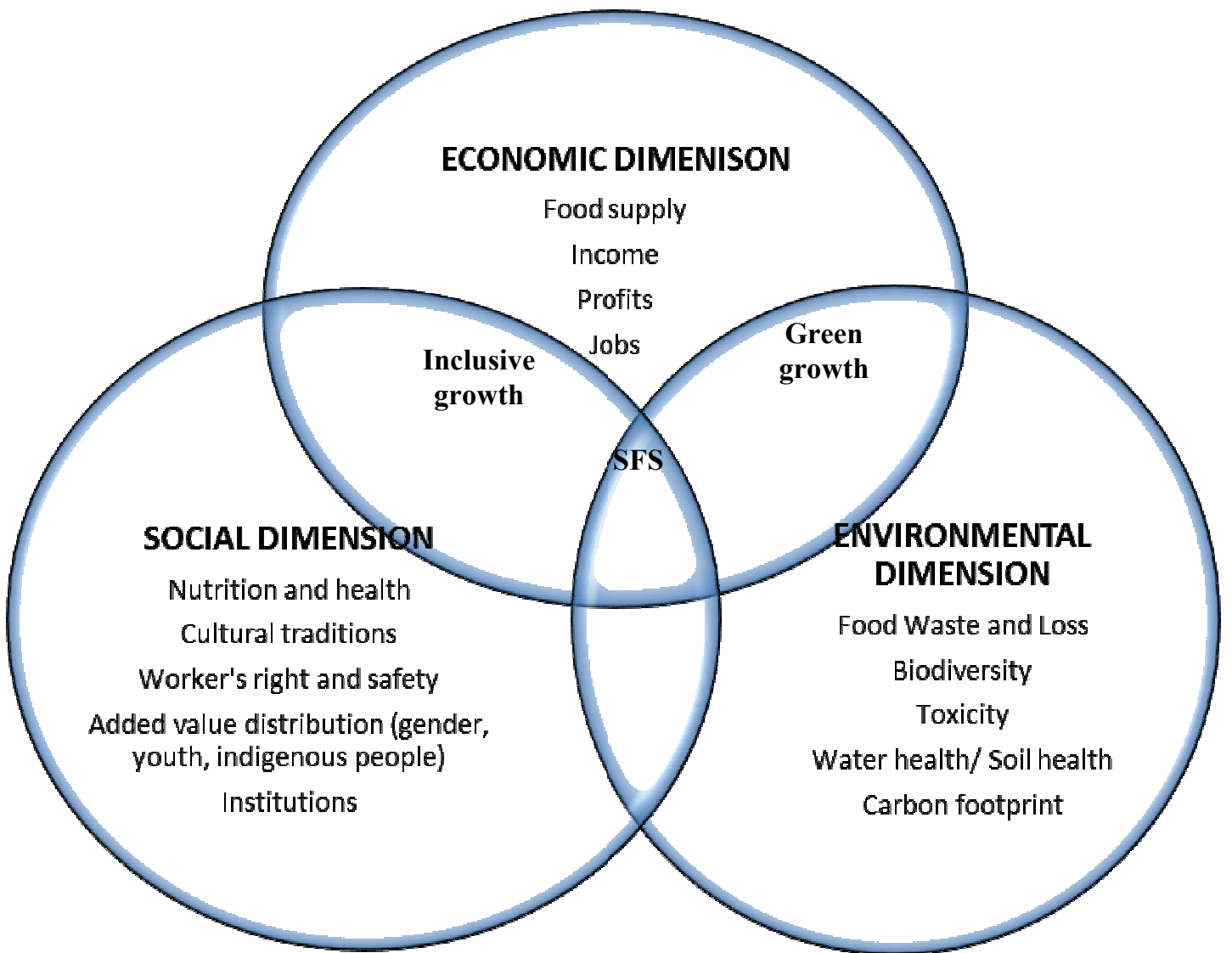

Figure 1: Sustainable food system dimensions and indicators Source: Adapted from Nguyen, 2018.

There is broad scientific consensus on what is needed to achieve a sustainable food system. This includes increasing or maintaining agricultural yields and efficiency while decreasing the environmental burden on biodiversity, soils, water, and air; reducing food loss and waste; and stimulating dietary changes towards healthier and less resource-intensive diets (European Commission, 2020). However, the interwoven interactions and feedback in the food system mean that direct interventions in one area risk creating or exacerbating problems in another (Nguyen, 2018).

This study assesses food system sustainability at the consumer level following the dimensions proposed by Nguyen and the European Commission. Hence, sustainability in this study is assessed in its economic, social and 
environmental dimensions. Following the ideas of Nguyen, in this study, a food system which is sustainable in the economic domain should provide sufficient food supply for households; for social sustainability, it should guarantee food security for all households; and for environmental sustainability, it should minimise household level food waste.

It is important to note that there will usually be trade-offs among the food system outcomes (social welfare, economic growth, and environmental sustainability) in the short term, and managers and decision makers will also often be concerned with how to resolve those trade-offs in the longer term (Ericksen, 2008). This study will verify the existence of such trade-offs in the context of the rural Cameroon food system.

\subsection{Food supply, food security and food waste in developing countries}

In most Sub-Saharan African countries, including Cameroon, there has been an increase in food availability since the second half of the period 1960-2013 (Berkum et al., 2017). However, Cameroon, like most SSA countries, is becoming more and more dependent on food imports. Statistics show a significant increase in the importation of animal products (meat, dairy and fish), cereals (including processed), fruits \& vegetables (fresh and processed), oils and fats, and other food products (mainly sugar) over the last 15 years for all regions of SSA (Berkum et al., 2017).

Table 1: Food imports in Cameroon (million USD) for 2000/2001 and 2014/2015

\begin{tabular}{|l|r|r|}
\hline Foods categories & $2000 / 2001$ & $2014 / 2015$ \\
\hline Animal products & 58 & 369 \\
\hline Cereals & 139 & 616 \\
\hline Fruits and vegetables & 6 & 23 \\
\hline Oils and fats & 9 & 26 \\
\hline Other (sugars) & 45 & 78 \\
\hline
\end{tabular}

Source: Adapted from Berkum et al., 2017

The data presented in table 1 shows that food imports for all food categories have increased over the past years. It appears from the table that the import bill for cereal and its products is much higher than for any other product category. Increasing food imports has led to higher import dependency for many products. When considering the share of imports in domestic food supply (in kcal/capita/day), food imports globally account for close to $10 \%$ of domestic consumption, but imports of fish, sugar, and cereals account for close to $60 \%, 50 \%$, and $30 \%$ of domestic consumption respectively (Berkum et al., 2017). Hence, in order to break this import dependency, Cameroon needs to step up its food production by putting in place serious measures.

Increases in the efficiency and productivity of food systems have resulted in successes around the world in reducing the prevalence of hunger and improving nutrition, but society still faces a number and range of food insecure situations, especially in Sub-Saharan Africa, where food insecurity persists (Ericksen, 2008). The 2017 Comprehensive Food Security and Vulnerability (CFSV) Analysis carried-out by the WFP in Cameroon revealed that approximately $16 \%$ of households in Cameroon are food insecure (moderately food insecure and severely food insecure). The WFP also found that a higher percentage of households in rural areas are food insecure than households in urban centres. At the regional level, the Far-North has the highest prevalence of food insecure households with $33.6 \%$, followed by the North West with $18.1 \%$ and the West with $18 \%$ (WFP and FAO, 2017).

The WFP and FAO reveal that a considerable proportion of households in rural areas $(26.8 \%)$ have inadequate diets and $5.4 \%$ of these households consume poor diets. The West region has the highest percentage of households consuming a poor diet $(9.3 \%)$. The increasing level of food insecurity in the West region is attributed to low consumption of milk with an average consumption of 1.5 days/week and low consumption of meat with an average of 0.9days/week (WFP and FAO, 2017).

Using the Food Consumption Score-Nutrition (FCS-N) analysis, it appears that most households with poor or borderline food consumption rarely eat protein and vitamin A-rich foods and are, therefore, likely not consume enough to meet their nutrient needs. Approximately $4.8 \%$ of rural households don't consume vitamin A-rich foods on a weekly basis, whereas $33 \%$ and $62.6 \%$ consume such foods between 1-6days/week and every day of the week respectively. Also, $6.2 \%$ of rural households don't consume protein-rich foods on a weekly basis, whereas $44.3 \%$ and $49.6 \%$ consume protein-rich foods between 1-6days/week and every day of the week respectively. On the other hand, $22.3 \%$ of rural households don't consume iron-rich foods on a weekly basis, whereas $59.8 \%$ consume iron-rich foods between 1 and 6 days a week and only $17.9 \%$ consume iron-rich foods on a daily basis. At the regional level, iron deficiencies are more pronounced in the Far-North, Centre and West regions, where the percentage of households who never consume iron-rich foods is $35.6 \%, 20.1 \%$ and $19.1 \%$, respectively (WFP and FAO, 2017).

The statistics presented by the WFP and FAO are slightly different from those presented by Tanankem and Fotio (2016). The latter, using the Calorific Contribution Approach to measure food insecurity, calculated the Household Calorific Availability per adult equivalent and revealed that the incidence of food insecurity in rural areas is about $33.8 \%$. On the other hand, analysis based on the FCS coefficients conducted by Soh et al. (2019) 
reveals that in the Bamboutos Division, West region of Cameroon, $12.16 \%$ of households are in a state of food insecurity, $55.41 \%$ are vulnerable to food insecurity and $32.43 \%$ are food secure.

There is rising food insecurity all over the world; meanwhile as already mentioned, every year one third (about 1.3 billion tons) of all the food produced for human consumption is either lost or wasted along the food supply chains (FSC) (FAO 2011; Capone et al., 2016; FAO, 2018). In medium-and high-income countries, food is to a great extent wasted, that is, it is thrown away even if it is still suitable for human consumption. Whereas in low-income countries, much less food is wasted at the consumer level, food is mainly lost during the early and middle stages of the food supply chain (FAO 2011).

Of the $35 \%$ of food loss and waste recorded in the world at the consumer level, developing countries account for 7\%, whereas developed countries are responsible for 28\% (Lipinsky et al., 2013; HLPE, 2014). Considering the quantity of loss and waste by weight, fruits and vegetables, roots and tubers, and cereals account for 44\%, 20\%, and 19\% respectively (Lipinsky et al., 2013). Food waste is minimal in SSA; it is completely absent for dairy products and it can be estimated at approximately $2 \%$ for cereals, roots and tubers, meat and meat products; below $2 \%$ for fish and sea foods; close to $5 \%$ for fruits and vegetables. On the other hand, Ramukhwatho et al. (2014) in a study in Mamelodi Township, South Africa, showed that 58\% of households throw away a lot of pap, rice ( $26 \%$ of households) and bread ( $16 \%$ of households).

Considering the inadequate level of food supply, the rising food insecurity and the non-negligible level of food waste in SSA, including Cameroon, this study presents an updated status of food system sustainability at the consumer level based on the above mentioned indicators.

\section{Methodology}

3.1 Area of study

The study was carried out in the West Region $\left(5^{\circ} 30^{\prime} 0^{\prime \prime} \mathrm{N}, 10^{\circ} 30^{\prime} 0^{\prime \prime} \mathrm{E}\right)$, which is one of the ten regions that constitute the Republic of Cameroon. It covers a surface area of 13,892 km2and is located in the central-western portion of the Republic of Cameroon (Kamga et al., 2017; Katabarwa et al., 2013). The region, whose headquarter is Bafoussam, is divided into eight (08) divisions, namely Bamboutos, Haut-Nkam, Hauts-Plateaux, Koung-Khi, Menoua, Mifi, Ndé, and Noun. It is the smallest of Cameroon's ten regions in area, yet it has one of the highest population densities (Katabarwa et al., 2013). The region has a total population of close to 1.8 million inhabitants and a population density of about 128.5 inhabitants $/ \mathrm{km} 2$.

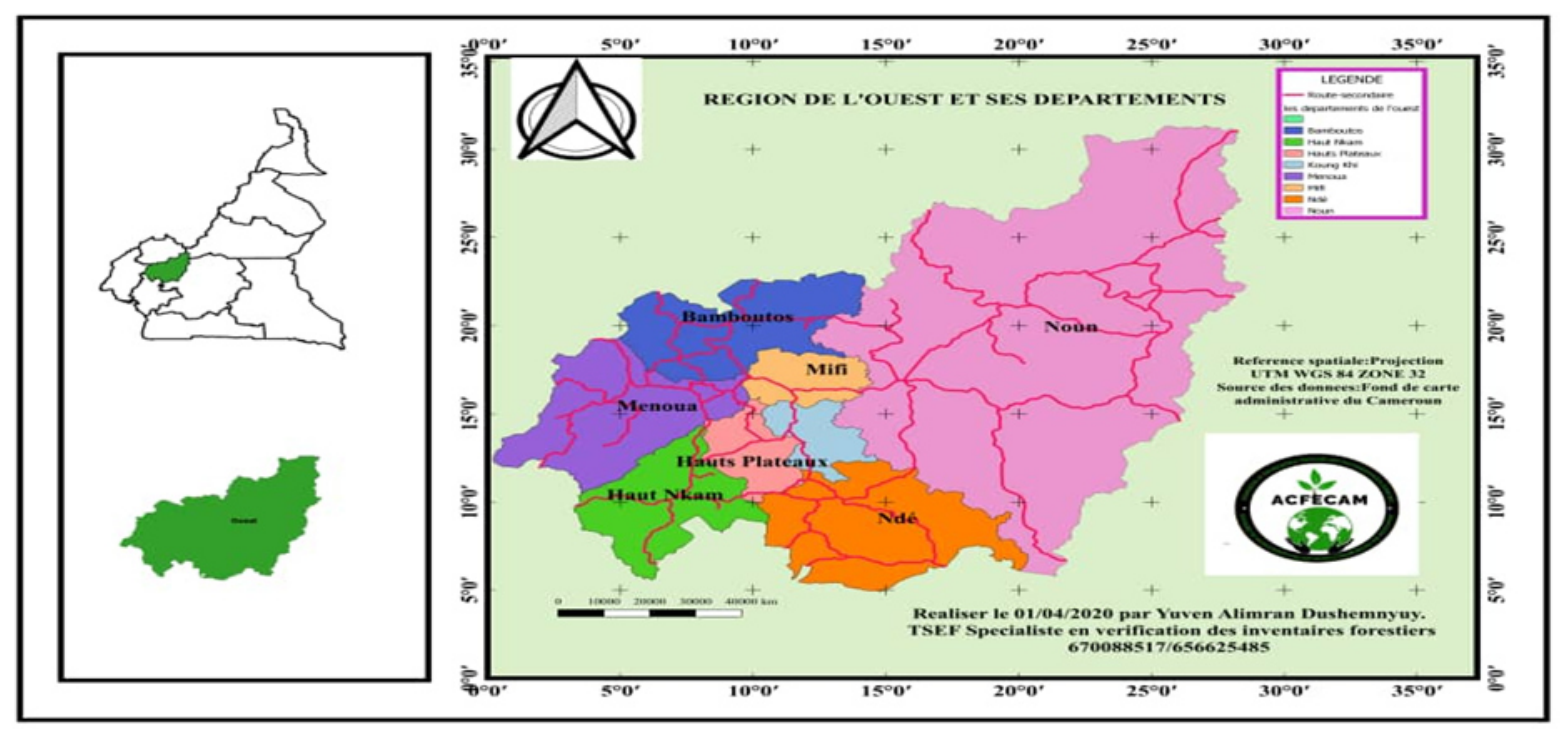

Figure 2: Map of the West region of Cameroon

According to the Third General Population and Housing Census (3rdGPHC), the west region is made up of approximately 348981 households, of which close to 147422 are found in the rural areas (BUCREP, 2005). The same source indicates that the average age for household heads is 48.5 years, which is above the national average (43.6 years) and $59.8 \%$ of rural households are male-headed, while $40.2 \%$ are female-headed in the West region.

The region is one of Cameroon's richest economic areas due primarily to its agricultural prosperity and the enterprising traditions of the Bamileke people (Kamga et al., 2017). In the West region, about $71 \%$ of the population are farmers and a quarter of households are involved in livestock production. The average cultivated surface is 1.3 ha and the main crops produced are maize (about $98 \%$ of HHs engaged in such crop production); beans (74\%); groundnut (40\%); whereas, millet, yam, and sorghum are negligible (WFP and FAO, 2017). 


\subsection{Data Collection process}

The data was collected from selected rural households involved in agricultural activities with the help of a wellstructured questionnaire. The study focused on rural households found in the West region of Cameroon. The West region of Cameroon was chosen as the area of study because agriculture is the main source of income for the rural population of this region. A multi-stage sampling method was used as follows: at the first stage, four divisions were randomly selected out of the eight in the region; at the second stage, three sub-divisions were randomly selected per division, giving a total of twelve subdivisions that were selected for the study; and at the fourth stage, a random selection of two (02) villages per sub-division was conducted; and at the fifth stage, 25 households were purposely chosen. At the end of the process, 600 households were selected for the purpose of the study.

\subsection{Methodological approach}

The aim of this study is to evaluate the economic, social, and environmental sustainability of the food system prevailing in rural Cameroon, with particular attention to the West region. Specific indicators are used to assess sustainability in the various dimensions of sustainability.

The rural household's food supply is used as an indicator to evaluate the economic dimension of food system sustainability. This indicator is measured on a household's self-reported basis using a three (03) item scale. The three scales for food supply are low, average and high.

The social sustainability of rural Cameroon's food system is evaluated based on food security and nutrition outcome indicators. This will be done by evaluating households' food and nutrition security status through the food consumption score (FCS) and food consumption score nutritional quality analysis (FCS-N).

The FCS is based on a 7-day reference. That is to say, a 7-day recall on the eight groups (cereals and tubers, legumes, dairy products, fruits, vegetables, meat and fish, sugars, oils) of foods (diversity) and the frequency of consumption. It is determined by the following formula..

$$
\mathrm{FCS}=\sum_{j=1}^{n}=a_{j} x_{j}
$$

With: $j=$ food group; $=$ number of days of consumption relative to each food group $(\leq 7$ days $)$; = weight coefficient of group $\mathrm{j}$ or Weight attributed to food group $\mathrm{j} ; \mathrm{n}=$ number of food groups that equals 8 . Based on their FCS, households are then classified into three categories: poor FCS (FCS $<21)$; borderline FCS $(21 \leq \mathrm{FCS}$ $\leq 35$ ); and acceptable FCS (FCS >35) which refers to food insecure, vulnerable to food insecurity, and foodsecured households respectively.

The household food waste, understood in the context of the study, as food that is of good quality and fit for human consumption but that does not get consumed because it is discarded either before or after it spoils, will be used to evaluate the environmental sustainability of the rural food system. Household level food waste is measured on a self-reported basis as applied to waste (Stancu et al., 2015; Visschers et al., 2016; Osmani and Kambo, 2018). Hence, household food waste is measured using a three-item scale indicating food discard frequency. The following scale is used to measure the frequency of food discards: rarely, frequently, and always. Ericksen (2008) and Nguyen et al. (2018) hold that there will usually be trade-offs among the food system outcomes (social welfare, economic growth, and environmental sustainability) in the short term. In order to verify the existence of such trade-offs, cross tables and chi2 tests will be used to link the various sustainability dimensions through their indicators.

\section{Results and Discussions}

\subsection{Demographic and socio-economic characteristics of households}

The socio-economic profile of the surveyed households is presented in table 2. The results related to the household head's gender show that a large majority of households $(77.33 \%)$ have a man as household head, whereas only $22.67 \%$ have a woman as household head. The average age for household heads is about 45 years old and about $80 \%$ of household heads are aged between 30 and 60 years. A majority of household heads $(26.67 \%, 51 \%$ and $24 \%)$ have received primary, secondary and tertiary education, hence are literate enough to understand the challenges and importance of strengthening women's empowerment. About $60 \%$ of households have between 5 and 10 members, and the average household size is approximately 6 people. Also, the main economic activity for the household head is agriculture for $56 \%$ of households, and crop production is the main agricultural activity for $81.67 \%$ of households. 
Table 2: Demographic and socio-economic characteristics of households

\begin{tabular}{|l|l|r|}
\hline Characteristic & Definition & Percentage \\
\hline \multirow{4}{*}{ Sex of household head } & Male & 77.33 \\
\cline { 2 - 3 } & Female & 22.67 \\
\hline & Below 30 years & 09.83 \\
\cline { 2 - 3 } & 30 to 40 years & 23.17 \\
\cline { 2 - 3 } & 41 to 50 years & 38.83 \\
\cline { 2 - 3 } & 51 to 60 years & 19.00 \\
\cline { 2 - 3 } & Above 60 years & 09.17 \\
\hline Education level & No formal & 04.33 \\
\cline { 2 - 3 } & Primary & 20.67 \\
\cline { 2 - 3 } & Secondary & 51.00 \\
\cline { 2 - 3 } & University & 24.00 \\
\hline \multirow{5}{*}{ Household size } & Below 5 persons & 35.33 \\
\cline { 2 - 3 } & 5 to 10 persons & 60.83 \\
\cline { 2 - 3 } & Above 10 persons & 03.83 \\
\hline Main economic activity & Agriculture & 56.00 \\
\cline { 2 - 3 } & Trade & 16.50 \\
\cline { 2 - 3 } & Civil servant & 15.50 \\
\cline { 2 - 3 } & Others (driving, tailoring etc) & 12.00 \\
\hline \multirow{5}{*}{ Main agricultural activity } & Crop production & 81.67 \\
\cline { 2 - 3 } & Livestock production & 18.33 \\
\hline
\end{tabular}

\subsection{Level of food system sustainability}

4.2.1 Food system economic sustainability

In the context of this study, an economically sustainable food system is one which guarantees a sufficient food supply for households. Hence, household level food supply is used in this study as an indicator of food system economic sustainability. Household level food supply is measured on a self-reported basis as low, average, and high, as depicted in table 3.

Table 3: Level of rural household food supply/availability
\begin{tabular}{|l|r|}
\hline Level of food supply & Percentage of total sample \\
\hline High & 37,17 \\
\hline Average & 63,50 \\
\hline Low & 06,33 \\
\hline
\end{tabular}

The results in table 3 show that $31.17 \%$ of households consider the household level food supply to be high. On the hand, $63.5 \%$ of households declare the household level food supply is moderate/average, while $6.33 \%$ claim the food supply is low. Hence, a considerable proportion of rural households in the region do not consider their farm output to be proportional to their efforts. In this regard, it can be concluded that the West region's food system is not economically sustainable given that a considerable proportion of households (approximately $6 \%$ ) consider the household level food supply to be low.

4.2.2 Food system social sustainability

Table 4 presents the households' food security status grouped in three categories.

Table 4: Rural household food security status

\begin{tabular}{|l|c|}
\hline FCS level & Percentage of total sample \\
\hline Acceptable FCS & 61,00 \\
\hline Borderline FCS & 21,17 \\
\hline Poor FCS & 17,83 \\
\hline
\end{tabular}

Overall, $61 \%$ of households have an acceptable food consumption score and are therefore considered as food-secured households; $21.17 \%$ have a borderline food consumption score implying that their diets are of inadequate quality; hence, they are moderately food-insecure; and $17.83 \%$ have poor food consumption scores implying that their diets are inadequate in terms of quality and quantity. This result implies that approximately $39 \%$ of rural households in the West region of Cameroon are food insecure, which is far above the situation reported by the WFP and FAO, who held that the prevalence of food insecure households in the West region stood at $18 \%$. The worsening situation can be explained by the high presence of internally displaced populations (IDPs) fleeing the neighbouring North West and South West regions that have been exposed to socio-political crises since late 2016. The West region was also one of the epicentres of the COVID pandemic that negatively affected the functioning of economic activities and probably had a negative impact on livelihoods.

In addition to FCS analysis, the food consumption score nutrition quality analysis was conducted because it 
helps to understand household level nutrient adequacy and attempts to improve the link between household food access/consumption and nutritional outcomes. The FCS-N uses data derived from the FCS module to provide information on three specific nutrients: hem iron, vitamin A and protein. Households are therefore grouped based on the frequency of consumption of the different nutrient-rich foods as presented in table 5 .

Table 5: Frequency of consumption of Hem-iron, vitamin A and protein rich foods

\begin{tabular}{|l|r|r|r|}
\hline Consumption frequency per week & Hem-iron rich foods & Vitamin A rich foods & Protein rich foods \\
\hline $\begin{array}{l}\text { Consume at least daily } \\
(7 \text { times or more in a week) }\end{array}$ & $26,17 \%$ & $69,17 \%$ & $72,33 \%$ \\
\hline $\begin{array}{l}\text { Consume sometimes } \\
(1 \text { to } 6 \text { times in a week) }\end{array}$ & $65,83 \%$ & $24,67 \%$ & $23,17 \%$ \\
\hline Never consume & $08,00 \%$ & $06,17 \%$ & $04,50 \%$ \\
\hline
\end{tabular}

Hem-iron consumption patterns show an alarming situation for the rural households because only $26.17 \%$ of households consume hem iron rich foods on daily basis whereas $65.83 \%$ consume them at least once in a week and $8 \%$ never consume iron rich foods in a week. This situation is worrisome because a considerable proportion of households are exposed to iron-deficiency disease such anaemia. However, the situation is less alarming when compared to the one presented by WFP and FAO (2017) who reported that $22.3 \%$ of the rural households do not consume iron rich foods on weekly basis whereas $59.8 \%$ consumes iron rich foods between 1 to 6 days in a week and only $17.9 \%$ consume iron rich foods on daily basis.

The results in table 5 also show that close to $6 \%$ of households never consume vitamin A rich foods on weekly basis whereas $25 \%$ consume them at least once in a week and $69 \%$ consume them at least daily. The results are close to those of WFP and FAO (2017) who reported that approximately $4.8 \%$ of rural households do not consume vitamin A rich foods on weekly basis whereas $33 \%$ and $62.6 \%$ consume such foods between 1 6/week and every day in a week respectively.

A considerable proportion of households $(72.33 \%)$ consume protein rich foods on daily basis ( 7 times or more in a week) whereas $23 \%$ consume them at least once in a week ( 1 to 6 times in an week) and $5 \%$ never consumed protein rich foods in a week (see Table 5). The results indicate that there are some improvements when comparing the results obtained to those presented by WFP and FAO (2017) which states that $6.2 \%$ of rural households do not consume protein rich foods on weekly basis meanwhile $44.3 \%$ and $49.6 \%$ consume protein rich foods between 1-6days/week and every day in a week respectively.

Based on the results obtained from the FCS and FCS-N it can be concluded that the food system prevailing in the West region is not sustainable in the social domain given that it is unable to guarantee food and nutrition security for all households. The frequency of consumption of the various nutrient rich food groups (hem iron, vitamin A, and protein) imply that the rural households do not probably have a mastery on the composition of adequate diets.

4.2.3 Food system environmental sustainability

In this study, an environmentally sustainable food system is one which minimizes food losses and waste at household level and is measured through the frequency at which food meant for household feeding are thrown away. Results presented in table 6 reveal that very few household tend to always discard food (1.33\%). Also, $13.5 \%$ of households discard food frequently whereas $85.17 \%$ rarely discard food.

Table 6: Frequency of food discards by rural households

\begin{tabular}{|l|r|}
\hline Food discard frequency & Percentage of total sample \\
\hline Always & $01,33 \%$ \\
\hline Frequently & $13,50 \%$ \\
\hline Rarely & $85,17 \%$ \\
\hline
\end{tabular}

The findings are supported by (FAO 2011) who posits that in low-income countries much less food is wasted at the consumer level; food is mainly lost during the early and middle stages of the food supply chain. The same authors adds that food waste is minimal in SSA probably due to the fact that poverty and limited household income make it unacceptable to waste food and because consumers in developing countries generally buy smaller amounts of food products at a time, often just enough for meals on the day of purchase.

4.2.5 Linking the sustainability dimensions

An attempt to link the various sustainability dimensions through their indicators is made in order to ascertain whether trade-offs exist between the various dimensions of sustainability. The results obtained here reveal that there is no trade-off between economic and social sustainability since the household food supply and food security move in the same direction (table 7). That is, as the percentage of household with high food supply rises, that household with a borderline and acceptable FCS rises as well. Also, there is no interdependence between the economic and social sustainability dimensions since the chi2 test result is not statistically significant. 
Table 7: Relationship between economic and social sustainability outcomes

\begin{tabular}{|l|l|l|l|c|}
\hline \multirow{2}{*}{ Food Supply } & \multicolumn{3}{|c|}{$\begin{array}{c}\text { Food consumption score } \\
\text { (\% of households) }\end{array}$} & $\begin{array}{c}\text { Chi2 test } \\
\text { (P-value) }\end{array}$ \\
\cline { 2 - 4 } & Poor & Borderline & Acceptable & Chi2(4)=3.8779 \\
$(0.423)$
\end{tabular}

On the other hand, the findings of the study reveal that a trade-off exists between the economic and environmental dimensions because the proportion of households that declared always discarding food rises as the food supply moves from low to average and high (see table 8). Also, there is some interdependence between these dimensions given that the chi2 test result is statistically significant (see table 8 )

Table 8: Relationship between economic and environmental sustainability outcomes

\begin{tabular}{|l|l|l|l|c|}
\hline \multirow{2}{*}{ Food Supply } & \multicolumn{3}{|c|}{$\begin{array}{c}\text { Food discard frequency } \\
\text { (\% of households }\end{array}$} & $\begin{array}{c}\text { Chi2 test } \\
\text { (P-value) }\end{array}$ \\
\cline { 2 - 4 } & Always & Frequently & Rarely & Chi2(4)=10.4881 \\
Low & 0.00 & 26.32 & 73.68 & $(0.033)$ \\
\hline Average & 03.94 & 09.97 & 86.09 & \\
\hline High & 03.87 & 10.50 & 85.64 & \\
\hline
\end{tabular}

Table 9: Relationship between social and environmental sustainability outcomes

\begin{tabular}{|c|c|c|c|c|}
\hline \multirow[t]{2}{*}{$\begin{array}{l}\text { Food consumption } \\
\text { score }\end{array}$} & \multicolumn{3}{|c|}{$\begin{array}{l}\text { Food discard frequency } \\
(\% \text { of households })\end{array}$} & $\begin{array}{l}\text { Chi2 test } \\
\text { (P-value) }\end{array}$ \\
\hline & Always & Frequently & Rarely & Chi2(4) $=26.0488$ \\
\hline Poor & 03.74 & 67.29 & 28.97 & $(0.0000)$ \\
\hline Borderline & 18.11 & 61.42 & 20.47 & \\
\hline Acceptable & 16.94 & 70.49 & 12.57 & \\
\hline
\end{tabular}

The results presented in table 9 also highlight the existence of a potential trade-off between the social and environmental dimensions of sustainability since the proportion of households discarding food frequently and always is greater amongst households with borderline and acceptable FCS. The chi2 test results also attest of the existence of some degree of interdependence between the two dimensions of sustainability through their indicators.

\section{Conclusion}

The study shows that the food system prevailing in the West region is not sustainable in the economic, social and environmental dimensions. However, sustainability issues are less alarming in the environmental dimension given the low level of food waste recorded. Also, the existence of trade-offs between sustainability dimensions such as food system's economic and environmental sustainability are observed through household food supply and food waste as well the trade-off between social and environmental sustainability dimensions show proof of the existence of negative feedback and interdependence between the different sustainability dimensions. Whereas the absence of such a trade-off between the economic and social dimensions shows evidence of the existence of positive feedback.

Acknowledgement

The authors are grateful to the rural household heads who provided the data needed for the study.

Funding

This work did not receive any special funding.

Conflict of interest

The authors declare no conflicts of interest.

\section{References}

Béné C., Prager, S. D., Achicanoy, H. A. E., Toro, P. A., Lamotte, L., Bonilla, C. \& Mapes B. R. (2019). Global map and indicators of food system sustainability. Scientific Data. 6:279 https://doi.org/10.1038/s41597-019-0301-5

Berkum, S. van, T.J. Achterbosch and V.G.M Linderhof, (2017).Dynamics of food systems in SubSaharan Africa; Implications for consumption patterns and farmers position in food supply chains. Wageningen, Wageningen Economic Research, Report 2017-072. 42pp.;11 fig.;6tab.;66ref.

Bogard, J. R., Marks, G, C., Wood, S., and Thilsted S, H., (2018).Measuring nutritional quality of agricultural production systems: Application to fish production. Global Food Security, Vol 16 pp 54-64.

Brown, M.E., Antle, J.M., Backlund, P., Carr E.R., Easterling W.E.,. Walsh M.K, Ammann C., Attavanich W., 
Barrett C.B., Bellemare M.F., Dancheck V., Funk C., Grace K., Ingram J.S.I., Jiang H., Maletta H., Mata T., Murray A., Ngugi M., Ojima D., O’Neill B., and Tebaldi C.. (2015). Climate Change, Global Food Security, and the U.S. Food System. 278 pages. Available online at http://www.usda.gov/oce/climate_change/FoodSecurity.htm

Bureau Central des Recensements et des Etudes de Population (BUCREP). (2005). Troisième Recensement Général de la Population et l'Habitat, Volume II Tome 4.

Caldeira, C., Corrado, S., and Sala S. (2017). Food waste accounting- Methodologies,challenges andopportunities. JRC Technical report Publications Office of the European Union, Luxembourg.

Capone R., Bennett A.,Debs P., Bucatariu C. A., El Bilali H., Smolak J., Lee W. T. K., Bottalico F., Diei-Ouadi Y., and Toppe J., (2016). Food losses and waste: global overview from a Mediterranean perspective. Part 2, Chapter 9. MEDITERRA 2016 Pp 194-242

Ericksen, P.J. (2008) Conceptualizing food systems for global environmental change research. Global Environmental Change, 18, 234-245.

European Commission (2020). Towards a Sustainable Food System.Group of Chief Scientifc Advisors. Scientifc Opinion No.8. European Commission, Brussels.

FAO (2011). Global food losses and food waste - Extent, causes and prevention. FAO, Rome Italy.

FAO. (2013). Sustainability Assessment of Food and Agriculture systems (SAFA).Rome (available at http://www.fao.org/nr/sustainability/sustainability-assessments-safa/en/).

FAO. (2014). Developing sustainable food value chains - Guiding principles. Rome

FAO (2015). SAVE FOOD: Global Initiative on Food Loss and Waste reduction. Rome Italy

FAO. (2018). Food loss and waste and the right to adequate food: making the connection. Rome. $48 \mathrm{pp}$

FAO, IFAD and WFP. (2013). The State of Food Insecurity in the World 2013. The multiple dimensions of food security. Rome, FAO.

FAO, IFAD and WFP. (2015). The State of Food Insecurity in the World 2015. Meeting the 2015 international hunger targets: taking stock of uneven progress.Rome, FAO.

FAO, IFAD, UNICEF, WFP and WHO. (2017). The State of Food Security and Nutrition in the World 2017. Building resilience for peace and food security. Rome, FAO.

FAO, IFAD, UNICEF, WFP and WHO. (2018). The State of Food Security and Nutrition in the World 2018. Building climate resilience for food security and nutrition. Rome, FAO.

FAO, IFAD, UNICEF, WFP and WHO. (2019). The State of Food Security and Nutrition in the World 2019. Safeguarding against economic slowdowns and downturns. Rome, FAO.

FAO, IFAD, UNICEF, WFP and WHO. (2020). The State of Food Security and Nutrition in the World 2020. Transforming food systems for affordable healthy diets. Rome, FAO. https://doi.org/10.4060/ca9692en

Gulisano,G., Strano,A., De Luca, A. I., Falcone, G., Iofrida, N. and Stillitano T. (2018). Evaluating the Environmental, Economic, and Social Sustainability of Agro-Food Systems Through Life Cycle Approaches. Chapter 4, Sustainable Food Systems from Agriculture to Industry. https://doi.org/10.1016/B978-0-12-811935-8.00004-4

IFPRI. (2015). Global Nutrition Report 2015: Actions and Accountability to Advance Nutrition and Sustainable Development. Washington, DC

IFPRI, Concern Worldwide, and Welthungerhilfe (2013). 2013 Global Hunger Index The Challenge of Hunger: Building Resilience to Achieve Food And Nutrition Security Washington, DC, Bonn, and Dublin.

IFPRI, Concern Worldwide, and Welthungerhilfe (2015).2015 Global Hunger Index.Armed Conflict and the Challenge of Hunger. Bonn/Washington, DC/ Dublin October 2015

IFPRI, Concern Worldwide, and Welthungerhilfe (2017). 2017 Global Hunger Index, The Inequalities of Hunger. Washington, DC / Dublin / Bonn October 2017.

IOM (Institute of Medicine) and NRC (National Research Council).(2015). A framework for assessing effects of the food system. Washington, DC: The National Academies Press. 445p

Kamga, G. R., Dissak-Delon F.N., Nana-Djeunga H. C., Biholong, B. D., Ghogomu, S. N., Souopgui, J., Kamgno, J. and Robert A. (2017). Important progress towards elimination of onchocerciasis in the West Region of Cameroon. Parasites \& Vectors 10:373 12pp DOI 10.1186/s13071-017-2301-7

Katabarwa, M. N., Eyamba, A., Nwane, P., Enyong, P., Kamgno, J., Kueté,T., Yaya, S., Aboutou, R., Mukenge, L., Kafando, C., Siaka, C., Mkpouwoueiko, S., Ngangue, D., Biholong, B. D., Andze G. O. (2013). Fifteen Years of Annual Mass Treatment of Onchocerciasis with Ivermectin Have Not Interrupted Transmission in the West Region of Cameroon. Journal of Parasitology Research Volume 2013, 12 pages http://dx.doi.org/10.1155/2013/420928

Lipinski B., Hanson C., Lomax J., Kitinoja L., Waite R. and Searchinger T. (2013), Reducing Food Loss and Waste. Working Paper, Installment 2 of Creating a Sustainable Food Future, Washington (D.C.), World Resources Institute

HLPE, (2014). Food losses and waste in the context of sustainable food systems. A report by the High Level 
Panel of Experts on Food Security and Nutrition of the Committee on World Food Security, Rome Food and Agriculture Organisation of the United Nations

Miller, G. D., Slimko, M., Tricarico, J., and Peerless, D. (2020).Food System Sustainability: A Dairy Perspective. Nutrition today. 55(2):82-85

Nguyen H. (2018). Sustainable food systems: Concept and framework. Policy Brief, FAO, Rome Italy

Osmani M. and Kambo A. (2018).Food waste factors of urban Albanian consumers-A multinomial econometric approach. European Scientific Journal Vol.14, No.3 pp 11-18.

Peano, C., P. Migliorini, and F. Sottile.(2014). A methodology for the sustainability assessment of agri-food systems: an application to the Slow Food Presidia project. Ecology and Society 19(4): 24. http://dx.doi.org/10.5751/ES-06972-190424

Prosperi, P.; Moragues-Faus, A.; Sonnino, R. and Devereux, C. (2015). Measuring progress towards sustainable food cities: Sustainability and food security indicators. Report of the ESRC financed Project "Enhancing the Impact of Sustainable Urban Food Strategies". http://sustainablefoodcities.org/getstarted/developingindicators

Ramukhwatho, F.R., du Plessis. R. and Oelofse.S. (2014). Household Food Wastage in a Developing Country: A Case Study of Mamelodi Township In South Africa. Proceedings of the 20th Waste Conference 6-10 October 2014. Somerset West, Cape Town

Segrè A., Falasconi L., Politano A., Vittuari M. (2014).Background paper on the economics of food loss and waste (unedited working paper) FAO, Rome Italy.

Sheahan M., and Barret, C.B (2017). Review: Food loss and waste in Sub-Saharan Africa. Food Policy 70 (2017) $1-12$

Soh W. B. D., Fon D. E. and Moluh N. H. (2019).Integrating nutrition in agriculture extension information and services and its implications for rural household food security in the Bamboutos division, West region of Cameroon. Journal of Agricultural Economics, Extension and Rural Development Vol. 6(7): pp, 781-790

Stancu V., Haugaard P. \& Lähteenmäki L., Determinants of consumer food waste behaviour: two routes to food waste, Appetite (2015), doi: 10.1016/j.appet.2015.08.025.

Tanankem VB, Fotio AH (2016). Food insecurity in rural households of Cameroon: Factors Associated and Implications for National Policies. Proceedings of the Seventh International Conference on Agricultural Statistics, Rome 24-26 October 2016.

Visschers, V.H.M., Wickli, N., Siegrist, M., (2016), Sorting out food waste behaviour: A survey on the motivators and barriers of self-reported amounts of food waste in households, Journal of Environmental Psychology, 45, 66-78.

Welthungerhilfe, and Concern Worldwide (2018). 2018 Global Hunger Index, Forced Migration and Hunger. Dublin / Bonn October 2018

WFP and FAO (2017). Cameroon: Comprehensive Food Security and Vulnerability Analysis. WFP and FAO, Yaoundé.

Zurek M., Hebinck A., Leip A., Vervoort J., Kuiper M., Garrone M., Havlík P., Heckelei T., Hornborg S, Ingram J., Kuijsten A, Shutes L., Geleijnse J. M., Terluin I., van 't Veer P., Wijnands J., Zimmermann A. and Achterbosch T. (2018). Assessing sustainable food and nutrition security of the EU food system-An Integrated Approach. Sustainability, 10, 4271; doi:10.3390/su10114271 